\title{
Class Politics and Migrants.
}

\section{Collective Action among New Migrants in Britain.}

\author{
Davide Però \\ University of Nottingham, UK
}

\begin{abstract}
This article addresses issues of class-based collective action. Through an ethnographic case study examining migrant workers' political engagements, the article discusses the current relevance of class politics and the role that culture, identity and intersectionality seem to play in it. By focusing on the collective political practices observed among Latin American migrant workers in London, it seeks to contribute to the 'new sociology of class', an emerging strand within the discipline which has begun to explore the identity and cultural dimension of class. In particular, it aims to broaden the scope of this strand beyond the individual so as to include the collective and contentious dimension of class and to enhance its sensitivity to new migrants and to the 'super-diverse' nature of contemporary society.
\end{abstract}

Keywords: class politics, culture, identity, intersectionality, Latin American migrants, trade unions, social movements, collective action.

\section{Introduction}

This article addresses issues of class-based collective action. Through an ethnographic case study examining migrant workers' collective agency, the article discusses the current relevance of these types of engagements and the role that culture, identity and intersectionality seem to play in them. By focusing on the collective political practices observed among Latin American migrant workers in London, it seeks to contribute to the 'new sociology of class', an emerging strand within the discipline which has begun to explore the identity and cultural dimension of class. In particular, it aims to broaden the scope of this strand beyond the individual so as to include the collective and contentious dimension of class and to enhance its sensitivity to new migrants and to the 'super-diverse' (Vertovec 2006) nature of contemporary society. 
The article will critically engage with the literature announcing the end of work, the society of work and the politics centred on work. It will also question 'essentialist' understandings of class politics that are unable to appreciate and examine the bottom-up political engagements of people - like migrants - who often undergo deskilling and 'complex' class repositioning, as well as of people who are not working class and yet engage in redistributive politics. It will dispute the tenability of representations of class politics as something intrinsically devoid of crucial identity and cultural aspects (see New Social Movements theory), as well as the related classificatory dichotomies that construct the material and the cultural as mutually exclusive. Focusing on the connection between class politics and culture (already outlined for example by Gramsci 1971, Williams 1977, Crehan 2002, Pratt 2003 and Ortner 2006) and applying it to the study of contemporary migrant workers' engagements, the article will also 'reclaim' culture from its exclusive assimilation to ethnicity (as customary in migration studies), and show how migrants - far from being politically quiescent or dysfunctional - can be actively engaged not only in building class-solidarity, but in building a class-solidarity which tries to be recognisant and representative of ethnic and gender diversity.

The article begins by critically engaging with the debate on class and class-based collective action that is found in sociology and social movements studies. This will be followed by a discussion of the approach, strategy, fieldwork and analysis. Then the article will look at issues of migration and integration in contemporary Britain as a way of introducing and contextualising the ethnographic case study on migrant workers and class politics.

\section{Class, Collective Action and Migrants' Engagements}

Since roughly the 2000 s a small but significant group of sociologists began to (re-) engage innovatively with class, a topic which in recent decades had slipped out of the main sociological agenda. They did so in terms of the study of class cultures, focusing on individualized and often tacit processes of hierarchical identification and differentiation as well as on the cultural and experiential aspects of being classed (e.g. Devine et al. eds. 2005; Savage 2000; Sayer 2005; Skeggs 1997). Some of this renewed attention for class has been deployed intersectionally, most prominently to examine the experience of being classed in relation to gender and women (Gillies 2007; Lawler 2000, Reay 2005), while less has been done in relation to ethnicity/race and migrants (Anthias 2005, Yuval-Davies 2011), with a 
few notable exceptions such as Kelly and Lusis (2006), Erel (2010) and Lopez Rodriguez (2010). These authors have recently shown how migrant workers often find themselves in complex processes of transnational class (re-)positioning where, due to deskilling, the fit between their educational qualifications and their actual work may be negatively altered. In doing so they highlighted the importance to acknowledge the heterogeneity of the population of contemporary society and avoid producing over-homogenising, ethnocentric and sedentaristic discussions of the experiences of being classed that assume geographic stability of the workforce.

If on the one hand this new 'culturalist' scholarship of class has certainly enhanced the understanding and appreciation of the workings of class in daily life at an individual, embodied and experiential level, on the other it appears to have stopped short of addressing collective engagements. In other words, class as a collective dimension of praxis and as a contentious collective identity has largely stayed unexplored (Bottero 2004; Devine and Savage 2005), as have contemporary class-based collective engagements and social movements.

In this article I contend that the study of class politics in contemporary sociology needs to be reintroduced not least because it constitutes a significant current social phenomenon. In doing so it is crucial to encompass the practices of migrant workers so as to avoid ethnocentric and assimilationist positions as their political practices cannot be subsumed to those of the sedentaristic population. However, this reintroduction requires some critical distancing from a number of well-established sociological perspectives regarding work, culture and class politics.

Firstly, it is important to realise that the end of work and the disappearance of the working-class (Gorz 1982; Offe 1985; Rifkin 1995) are far from unequivocal (see Mayo 2005; Munck 2002; Dinerstein and Neary 2002; Holloway 2002; Cleaver 2002; Standing 2009, 2011). At a global level the workforce has doubled since the 1960s (Mayo 2005), and in rich countries poorly paid, precarious, unskilled and semi-skilled jobs have multiplied, resulting in a demand which has partly been filled by migrant workers (Standing 2011; Wills et al. 2010). In addition, under neo-liberal globalisation the question of socio-economic justice has intensified with a growing number of people worldwide experiencing precarious life conditions as result of weakened connections to work (Standing 2011). In this context, 
labour and class-based disputes, while less prominent than before, are still occurring worldwide and are at times re-energized (Moody 1997; Wills 2008).

Secondly, it is important to realise that the view of culture as something alien or counterpoised to class that has come to dominate the discipline is ultimately detrimental to sociological analysis. With the (supposed) end of work and of the society of work just mentioned, since the 1980s sociology has withdrew from the study of class (Devine and Savage 2005, Reay 2011; Sayer 2005; Skeggs 1997; Meiksins Wood 1998; Moschonas 2002) with a simultaneous shift in focus from redistribution to recognition (Fraser 2000). ${ }^{1}$ Often referred to as the 'cultural turn', this shift has brought a much needed sensitivity to issues of identity and culture and resulted in a more sophisticated analysis of other - until then neglected - axis of inequality such as gender, race/ethnicity, generation and so forth. However, this shift has also meant ignoring class, treating it as if it had little to do with identity and culture and as if it did not intersect with these other axis of inequality in crucial ways. Moreover, this shift has been characterised by an idea of recognition largely interpreted in essentialist terms and as something decoupled from material justice (Fraser 2000; 2005). As observed by Reay, 'over this period social class increasingly became the lost identity of identity scholarship' (2011:1).

Thirdly, it is important to realise that framing conflict in contemporary society merely as a post-material phenomenon, embodied by social movements that are qualitatively different from those based on class (now supposedly extinct) is also problematic. The most influential streams in the study of collective action - and in particular the New Social Movements (NSM) approach (e.g. Touraine 1971, 1981; Melucci 1989; Eder 1985) - have been theorising 'away' from class (Nash 2010; Della Porta and Diani 2006; Polletta and Jaspers 2001; Fraser 2005). Until the 1960s, Marxism - which considered capital/labour as the central societal conflict - was the prevailing model of interpretation of social conflict in Europe (Crossley 2002; Della Porta and Diani 2006; Goodwin and Jasper eds. 2009; Ryan 2006; Nash 2010). However, this framing was increasingly regarded as inadequate in terms of making sense of the then emerging expressions of collective action that were not about the control of economic resources and means of production. These emerging conflicts and the movements that articulated them from the second half of the 1960s were seen by the NSM theorists as qualitatively different from the 'old' labour movements. According to Della Porta and Diani (2006): 
'Among the principal innovations of the new movements, in contrast with the workers' movement, are a critical ideology in relation to modernism and progress; decentralised and participatory organizational structures; defence of interpersonal solidarity against the great bureaucracies; and the reclamation of autonomous spaces, rather than material advantages' (p. 9; my emphasis).

Thus, while still crucially concerned with conflict and collective action as central social phenomena, the NSM scholars developed a critical, reflexive, and engaged approach centred on identity, culture, cultural contestation and recognition, and the individual (Crossley 2002; Melucci 1989; Nash 2010). These elements in their eyes had little to do with class, which they saw as merely about material/economic gains. Similarly, the collective actions that were based on class were perceived and portrayed as old and superseded (Goodwin and Jasper 2009; Ruggiero and Montagna 2009). In fundamental ways NSM theorists saw conflict as cultural rather than economic in an understanding of the cultural and the material as not only separate but also mutually exclusive (Pratt 2003). In defining the new social movements so strongly against the labour movement and class struggles, these authors have contributed to make class-based struggles invisible as well as sociologically under-theorised, precisely at the time when neo-liberal restructuring has been intensifying. In Nancy Fraser's words 'the turn to recognition dovetailed all too neatly with a hegemonic neoliberalism that wanted nothing more than to repress all memory of social egalitarianism' (2005: 299).

Finally, it is also important to highlight that the refusal of some scholars (often Marxists) to engage with issues of identity and culture as deemed marginal or misleading does not constitute a viable alternative (Devine and Savage 2005; Dworkin 2007; Gilroy 2002). This attitude can be observed, for example, in Industrial Relations, a field of study that has paid scant attention to dimensions of oppression other than class (as critically observed by Holgate 2005; Martínez Lucio and Connelly 2010), an attitude that has done little to halt the marginalisation of class politics as object of study. At the time when the work force has changed considerably from that of the industrial era featuring an ever higher proportion of women and migrants occupied in the tertiary sector, issues of gender, ethnicity, citizenship, recognition and so forth need to be intersectionally considered with those of class in the study of workers' political engagements.

This article builds on the contribution that the NSMs approach and the cultural turn more broadly have made to the scholarship on collective action by highlighting the 
significance that culture, cultural contestation, identity, subjectivity and recognition play in mobilisation and it does so by applying it to the study of class politics. Given my concern for both the cultural and the material dimensions of class and class politics I define class politics as: the individual and/or collective acts intended to mitigate or deny claims made on subordinate groups of people by dominant ones (including employers, landlords, and the state) and/or to advance the claims of a subordinate group (e.g. with regard to work, rights, land, respect and recognition). This definition is derived from the work of James Scott (1985: 290); I have tried to retain its original focus on the material basis of contention without excluding the cultural practices that challenge the hegemonic and authoritative framings of justice, fairness and equity. Also included is an appreciation of intentions (even though the intended outcome are not achieved), and the possibility that class acts do not need to be articulated or perceived as such by their enactors. Moreover, this notion tries to reflect an 'anti-essentialist' stand (Laclau 1994; Gibson-Graham et al. 2000; Gilroy 2002; Ortner 2006; Wills 2008), by not confining the enactors of class politics to a necessarily disadvantaged class position. In other words, one need not be 'working class' to be involved in practices aiming at improving the conditions of socio-economically disadvantaged groups, as seems to be implied in Scott's definition (see Gledhill 2000; Ortner 2006). This inclusionary and antiessentialist conception of class politics seems especially relevant to study people who undergo complex processes of class repositioning, as often is the case with migrants. ${ }^{2}$

The case study presented below concerns the engagements of migrant workers and some of their advocates with special reference to the cleaning sector in an urban context. The rationale behind it has been to try and avoid abstract, top-down and detached formulations on collective action and instead produce inferences that are grounded in empirical research on the lived experiences of the research participants (Devine and Savage 2005; Milner 1999; Ortner 2006).

\section{Methodological Issues}

The case study has centred on a multi-sited ethnography (Marcus 1995; Però 2007a) conducted across a number of initiatives, localities and scales. This research involved, first, identifying and developing rapport with a groups of migrant workers who were trying to improve their conditions and then follow them through in relation to the relationships, events, and initiatives in which they got involved as part of their socio-political practices. Fieldwork 
comprised a great deal of participant observation and conversations in order to understand some of the participants' point of view in context (Okely 2012), as well as semi-structured interviews and document collection. In this way, in addition to gaining a sound grasp of the participants' views, what they said they did in interviews and documents they authored was being compared with what they appeared to be doing in the eyes of the ethnographer.

This research is part of a wider ongoing project on the civic and political participation of migrants in Britain which involves the examination of other initiatives that would fall beyond the scope of this article. The ethnographic nature of this project, which was carried out with varying intensity over six years, makes it hard to quantify the amount of participant observation and the number of informal conversations that this article draws on. However, as an indication, in relation to the subject of this article, I have carried out participant observation at 34 events and conducted 31 semi-structured interviews. Fieldwork was conducted at formal and informal meetings and training sessions organised by the Latin American Workers Association (LAWAS), the T\&G-Unite, and community organisations, demonstrations, protests, marches, round tables, community events, recruiting activities as well as in cafes and pubs and in private homes. The interviews and informal conversations involved LAWAS members, T\&G-Unite organisers and leaders, and some of their interlocutors and collaborators in a range of different initiatives. It also involved examining some of the texts that the participants and their organisations had produced. The analysis of the material gathered has been conducted using the 'funnel approach' developed by Agar (see also Okely 1994 and 2012). This is part of a wider, open-ended and holistic research approach (typical of ethnography) that allows for themes, ideas, hunches, patterns and priorities to gradually emerge and impose themselves upon the ethnographer in complex and often unexpected ways, from the beginning of fieldwork to the completion of the writing up stage, as insightfully explained by Okely (1994).

\section{The Case Study ${ }^{3}$}

As part of the process of global neo-liberal restructuring since the early 1990s the UK has experienced significant new migrations. Unlike those that arrived during the 1950s and 1960s, these tended to lack a direct colonial link with Britain, and they largely originated in developing countries outside the Commonwealth. The new arrivals have been mostly noncitizens who entered the country with different, more fluid and precarious statuses (asylum 
seekers, students, the undocumented, overstayers, temporary workers etc). The number of nationalities and languages increased accordingly to the point that, later, commentators began to speak of 'super-diversity' (Vertovec 2006) to describe the situation of an already multiethnic society (characterised by the presence of long-standing ethnic minorities) receiving such a diverse new migratory flow. Among these groups we find Latin American nationals (McIlwaine et al. 2011) whose political practices are the focus of the case study discussion. Like other new migrants they often experienced deskilling (Kelly and Lusis 2006; Erel 2010), finding occupation in sectors of the economy - such as cleaning - that 'locals' reject due largely to the precarization and low status of such jobs (Wills 2008; Standing 2011). In terms of public and policy discourse the new immigrations started to be addressed largely during the 2000s. During that time the European country that perhaps more than any other had previously distinguished itself for its liberal and pluralist way to promote integration and recognise diversity, relinquished multiculturalism and embraced the neo-assimilationist framework of 'community cohesion' (Grillo 2005; Kundnani 2007; Lentin and Titley 2011; McGhee 2008 ; Però 2008; Però 2013). It is in this context that this article now discusses the experience of a group of migrant activists and their organisation LAWAS and the wider movements and initiatives they have been part of.

After a more informal existence that lasted several months, in the second half of 2004 the founding members of LAWAS managed to incorporate their organisation in one of the largest British trade unions, the Transport and General Worker Union (or T\&G), that subsequently transformed into UNITE. LAWAS's main goal was to combat more effectively the exploitation and exclusion afflicting much of the Latin American migrant population in London. According to Fernando, one of the four Latin American trade unionists who founded it:

'LAWAS is the product of a necessity, which has emerged progressively after many Latinos had solved their immigration, housing, and benefits problems. ... Besides addressing some of the exploitative aspects experienced by Latinos workers in Britain, LAWAS struggles for helping the Latinos workers coming out of their invisibility with dignity, not by "asking" (pedir) but by "demanding” (exigir). Together with other workers organization - the Portuguese, the Turkish, the African—we share the same class need [necesidad de clase]'. 
The sphere of work was seen as a critical one to address as, while so crucial to quality of life, it was left largely uncovered by both the existing Latin American community organisations and the British labour organisations. In fact, the former addressed issues ranging from immigration papers to domestic violence but not issues of exploitation and abuse at work. At the same time the labour organisations, despite being formally supportive of migrant workers, were in practice hardly accessible to them due to lack of awareness and trust, language and communication barriers and inadequate efforts on the part of such organisation to reach out to them. According to Irene, who was one of the first activists to join the founders in running LAWAS:

'The Latin American community is ignorant with regard to their employment rights. There is a lot of exploitation. They steal from them all the time and it is great that LAWAS has been set up'

A key dimension of the politics of LAWAS is its intersectionality, particularly between class and ethnicity. The hallmark of its politics revolves around class but it is intended to speak primarily to members of a specific macro ethnic group, Latin America's migrant workers. In fact, rather than using ethnicity in essentialist ethno-nationalist terms, LAWAS seems to use it mostly in a strategic (Spivak 1996), flexible and pan-ethnic (Espiritu 1992) manner so as to represent and integrate workers with significant linguistic and ethno-cultural affinities into a wider universalist egalitarian project such as that expressed by the labour movement. LAWAS's approach is very different from that of other 'political' Latin American organisations that have engaged in 'integration from below' initiatives (such as the Latin Front and The Iberoamerican Alliance; see below and Però 2008) and that have also made use of strategic ethnicity and pan-ethnicity. While LAWAS had a clear primary justice agenda connected mostly (but not exclusively) to the sphere of work, the other organisations had an inter-classist agenda primarily concerned with ethno-cultural and legal recognition.

In the specific class politics that LAWAS set out to articulate a number of interconnected strands can be identified. A working typology with a heuristic and illustrative purpose would include, first, what we could call 'contractual improvements'. This first strand focused on negotiations concerning pay (often well below London's living wage), unfair dismissal, sick leave and annual leave entitlements (often not granted). The second strand looked at tackling workplace oppression. As pointed out by Ines the forms of oppression recurrently encountered by Latin Americans workers included 'sexual harassment, psychological 
maltreatment... verbal abuses and discrimination of all sorts'. The third strand of LAWAS's politics was perhaps less connected to the workplace and more to the figure of the worker and his/her 'recognition'. In other words, LAWAS has been strongly engaged in promoting both the legal recognition of migrant workers' presence and the ethno-cultural recognition of Latinos as an ethnic minority. In addition, LAWAS has been engaged in enhancing the visibility of Latino workers and their respectful treatment at work as well as in society more generally. As Maria, who joined LAWAS in 2009, stated:

'LAWAS is about finding a space where you as worker and migrant can collectively find a voice to be recognised to be heard in British society. It's a space... of encounter between Latinos themselves and from there with British society as well I would say... It's also ...a space where we are everything that we cannot be elsewhere because there is no space elsewhere for us to be vocal or exert our power.'

As issues of identity and culture have been portrayed in the literature as not pertaining to the domain of class and class-based collective action, it is important here to provide a sense of how on the contrary these dimensions seem to interact. A key issue in this respect concerns the cultural-political identity of LAWAS activists. The founders all had a history of trade union militancy in their countries of origin and their (forced) migration was connected to that. Their political background and identity appear to have played a very strong role in influencing their participation in LAWAS and indeed its creation. For example, for Pedro who then went on to become a full-time union organiser in Britain - his involvement in LAWAS was strongly connected to his personal history of labour movement activism in Latin America. Indeed, his activist past played a key role in overcoming the deskilling that, like other migrants, he was experiencing. In fact, as his professional education and training were deemed invalid in Britain, he became determined to pursue a professional career as union organiser, using his past experience and cultural capital as well as his LAWAS-related experience and networks. Pedro's case is reminiscent of that of Nâlan - the migrant activist discussed by Erel (2010), who creatively redeployed her cultural capital and previous civic and political experience to combat her downward mobility and find gratifying professional employment in the British social work sector.

Many other key members of LAWAS also had a history of left-wing activism even if not directly in trade unions, as in the case of Irene who was a community activist working on educational matters in impoverished areas in her country of origin. Others, such as Ines and 
Maria, had also been actively engaged with disadvantaged groups prior to migration, even though their political identity then was perhaps less connected to the secular left than to the liberation theology doctrine.

While to most of its activists LAWAS constitutes their primary means of political action, to some it was merely one of their many acts of engagement across a range of organisations. For example, Arturo was almost entirely dedicated to LAWAS, while Irene was also very heavily involved in a transnational organisation promoting justice and democracy in her country of origin and with a Latin American women's organisation. Some became involved in LAWAS 'directly', because of their political identity, others came across LAWAS through the grievances that they or their friends had experienced at work. For the latter, grievances appeared to have acted more as a wake up call for an existing political identity and sensitivity that had yet to develop into something more concrete in Britain than as the development of a whole new political consciousness. For example, Ines and Maria both made the decision to get involved in LAWAS after being abused in the London shop where she worked (Ines), and after a very stressful year struggling to secure the right to remain in Britain (Maria).

'I myself had a case and after solving that, I stayed on working with them [LAWAS] as a volunteer...It was these needs that I had that produced these feelings that this has to stop some day and that one has to do something about it.'

For some their social and political networks were important in connecting them to LAWAS, for others LAWAS was reached via other routes, e.g. via information conveyed through community radio programmes and other community organisations. The organisation encouraged a collective identity, conferring on members a sense of themselves as part of a supportive group, with the belief that investing in it was rewarding not just in terms of ameliorating their own situation but also in terms of non-material and emotional rewards. LAWAS gave its activists a sense of pride and identity, a feeling that they were shaping their lives and those of their fellow Latino workers, despite the disadvantageous and exclusionary conditions being encountered. It embedded them in a solidarity circuit where class and ethnicity are interwoven, making them feel stronger and cared about. As Ines points out:

'I have always wanted to help my community here... and having worked in many restaurants, cafes and other places I witnessed abuses all the time and said to myself this can't be. There must be a door where they could knock and be listened to... I love to see them being respected, to stop people taking advantage of them ... even if they 
are illegal they are human beings and they have rights ... Realising that I could do all this was very satisfactory'.

Thus, we can say that LAWAS's class politics is concerned with representing the interests of Latin American workers in Britain, but also with empowering them, articulating their views and expressing their identities and feelings.

The multifaceted and intersectional class politics of LAWAS also entailed seeking to enhance its impact in a number of different yet partly overlapping directions. The first direction has involved formally joining the trade union T\&G-Unite just before it began a large scale and innovative campaign targeting the cleaning sector (mostly employing migrant workers) in large companies. This campaign was called Justice for Cleaners, and was based on the model of the Justice for Janitors campaign that took place in the US a few years earlier (see Wills 2008); it also drew on 'social-movement unionism' (Moody 1997) whereby unions actively collaborate with other civic and community organisations. Justice for Cleaners consisted of recruiting, organising and training exploited cleaners so as to create largely selfreliant trade union outposts at the workplace. The unionised workers could then negotiate directly and in situ with the management of the cleaning contracting companies hired by 'big' companies such as international banks, the London transport authority and even the Houses of Parliament. Rodrigo, an Ecuadorean cleaner who joined the union through the campaign, described his involvement as follows:

'Joining the union has been good because now we feel a bit stronger, because if they ignore our demands we can send a letter from the union directly to the boss of our supervisors. ...Things like "you are useless today we don't pay you, go home and come back tomorrow" It's very humiliating, it make you feel very low... So it has meant primarily to be treated more politely and with greater respect and secondly it has involved a better wage.'

The originality of the campaign lay in the way that, in a post-industrial era characterised by hegemonic neo-liberal ideology, the trade union went on the 'offensive' and targeted a new constituency, such as the cleaners, who were almost entirely new migrants. It was also innovative in trying to induce the cleaning contractors to negotiate, so that the union worked on the 'outside' at the same time as on the 'inside', e.g. by staging protests outside the big reputable companies (such as banks) that hired the exploitative cleaning contractors. The protest would put pressure on the company by shaming them vis-a-vis public opinion and the 
media for allowing exploitative and unethical practices to take place on their premises, inducing them to demand that their cleaning contractors accommodate the union's requests. In this way, caught with pressure from below and inside as well as above and outside, the exploitative cleaning contractors generally gave in to the trade union requests for a living wage, sick leave entitlements and so forth. Another element of innovation consisted in recruiting and training young, educated organisers from social movements and radical organisations involved in campaigning for migrants' rights and freedom of movement - e.g. No Borders - some of them being migrants themselves. The campaign was innovative also because it adopted a 'like for like' approach, training migrants from particular nationalities or ethnicities as organisers, thereby overcoming language barriers and helping to establish trust. It is in this context that a key member of LAWAS was selected to become a full-time union organiser to be deployed in the campaign. Migrant workers were thus being recognised as a resource both for the growth and for the functioning of the union. As a consequence the composition of the union started to change with new migrants now becoming a key component. However, there were also more ambivalent implications of LAWAS's 'like for like' strategy as some of its most valuable human resources were used elsewhere. This situation created friction that added to the reservations that LAWAS leaders had with regard to contemporary British unionism as Fernando explained:

'What has happened in Britain is that the union leadership has managed to make its base believe that they are not needed. As a result the base is now dormant. It's like having one of your arms resting in a cloth hanging round your neck all the time without it ever being used, it atrophies it will not respond... But historically anywhere in the world trade unions struggles are done through practice not with the approval of the bosses or of the people with money, things have been achieved because they have been seized. So here the power to struggle has gone lost.'

A second direction in which LAWAS channelled its energies was its involvement in London Citizens, a broad-base social movement with a significant class justice dimension (see Wills 2008). This was a large-scale initiative made up of numerous community organisations (including churches and mosques) and other trade unions which campaigned for citizens' rights ranging from the living wage to the regularization of undocumented migrants. Becoming part of the T\&G-Unite meant that LAWAS automatically became part of 
the wider movement. However, involvement in London Citizens was not a routine move happening almost by default, but something LAWAS actively participated in. However, later LAWAS criticised London Citizens' campaign 'Strangers into Citizens' - the campaign for the regularisation of undocumented migrants - as their proposal of amnesty would only benefit a small number of unauthorised migrants. This position was consistent with the statements I repeatedly heard during fieldwork, LAWAs members feeling that workers and people more generally cannot be made 'illegal', and that union membership has to be accessible to irregular migrants as well.

Third, LAWAS engaged actively and systematically on other fronts which for reasons of space cannot be discussed here with the exception of the Latin American Recognition Campaign (LARC). LAWAS's particular class politics has been tightly and inextricably intersected with ethnicity. This intersection is not only to do with organising a relatively homogeneous linguistic and ethno-cultural group of workers in the sphere of employment and rights (in the ways that have just been illustrated) but is also concerned with campaigning to be recognised as an ethnic minority on a par with more long-standing groups. This desire grew progressively stronger among London's Latin American migrant population until 2004 when the Latin Front was created (see Però 2008). This was then succeeded by the Iberoamerican Alliance, a name that intended to represent migrant populations from Spanish and Portuguese speaking countries on both sides of the Atlantic including Spain, Portugal, Brazil, Angola and so forth. While this Alliance clearly promoted the visibility of the Latin American 'community' in the eyes of the London politico-institutional establishment (the London mayor Boris Johnson attended some of their events) they also managed to raise considerable discontent from within the Latin American 'community', especially from groups characterised by a critical and egalitarian political identity. The idea of using this colonial term for seeking recognition in Britain ran counter to their historical consciousness and collective political identity and culture, clashing with the liberation, indigenous and class struggles so many of them identified with. These attitudes are illustrated in the following public statement (made on 31-3-2011) by one of the LARC's leaders, Claudio Chipana:

'Not only are Latin Americans not recognized as an ethnic minority in the United Kingdom, but similar to other migrants and the entire working class population in this country, they suffer the onslaught by the current coalition government against basic 
services such as health, education, housing and employment. The issue of recognition for minorities cannot be seen separately from the conditions of a dignified life for all, including the migrant communities'

This involvement of LAWAS in LARC shows again how class and ethnicity intersect in its politics. While the organisation's main focus may be ethnic recognition, it is clearly expressed from a broadly socialist and anti-colonial perspective, demonstrating how ethnicity can be negotiated through class.

\section{Conclusions}

From the case study a number of conclusions can be drawn. One concerns the enduring relevance of struggles against socio-economic inequality. Current class-based collective engagements may perhaps be less conspicuous, visible and recognisable than during the industrial era, but they still constitute a significant social phenomenon, and one that extends outside the workplace. Also, the articulation of these class engagements comprises new global citizens such as migrant workers, and contrasts with the methodological ethnicity (Glick Schiller 2008) that by default frames migrants' behaviour in terms of ethnicity. Moreover, these engagements seem broadly consistent with those discussed in other recent works in the context of migration and integration (e.g. Anderson 2010; Hearn and Bergos 2011; Korczynski and Zhang 2013; Wills 2008; Wills et al. 2010; Però 2008). Indeed, these new migrants' mobilisations, together with those for the regularisations of unauthorised migrants (Chimienti 2011; McNevin 2011), appear to be a feature of the current advanced neoliberal globalisation, rather than an anachronism. Taken together these empirically based studies seem to reinforce the criticism that more theoretical works (e.g Dinerstein and Neary 2002; Holloway 2002; Cleaver 2002; Standing 2011; Fraser 2005) have moved to the body of literature that sentenced the end of the society of work, class and related contentious politics (e.g. Gorz 1982; Offe 1985; Rifkin 1995).

Also, contrary to the prevailing treatment of migrant workers as objects of policy or passive victims (Però and Solomos 2010; Però 2011), this sector of the population - despite its often very precarious conditions (Standing 2011) - has emerged as able to engage collectively with exploitative and marginalising processes as well as helpful in reinvigorating the labour movement. The creation of LAWAS seems a clear illustration of this bottom-up, 
class-based solidarity that Korczynski and Zhang (2013) referred to as "communities of coping'.

A further point made through the case study concerns the scope of class-based collective actions, the rationale for the participants' involvement and the rewards they obtained from undertaking such actions. These actions are in fact about both material pay and conditions, as well as non-material issues such as respect, recognition, dignity, pride, empowerment, solidarity, rights and representation in the workplace and more widely. This is relevant not only because it confirms the findings of some historical and socioanthropological studies concerning the industrial era (e.g. Pratt 2003) but also in showing how this simultaneity very strongly characterises the class-based politics of the current postindustrial neo-liberal era.

Moreover, issues of identity and culture (often in conjunction with personal grievous circumstances) have emerged as crucial for the articulation of the range of class-based intersectional collective actions described. For example, the trade union experiences I presented in the case study indicated a growing awareness of the importance of recognising and accommodating ethno-cultural diversity in organising action among migrant workers (such as the 'like for like' strategy). They also showed how these class engagements have been articulated in an 'intersectional' manner, even though - as we have seen - this intersection may have been incomplete, shifting or even at times contradictory and contested by some of the actors involved. Also the significance of culture and identity issues became apparent when the collective action was extended outside the workplace and involved other players. Migrant workers, through their own organisations and with the help of unions and community organisations (like London Citizens), brought disputes about employment relations into the streets, in the 'community', into the court of public opinion, challenging employers' behaviour in the public realm (see also Wills 2008). Protesting in the streets (e.g. outside banks in central London) constitutes an appeal to the cultural values of equity and sense of fairness of many people (as consumers, general public, etc). This practice was not something separate from the material dimension of the struggle but part and parcel of a response to employers' attempts to develop ever more distant relations through the use of subcontractors and employment agencies. However, it is worth noting that migrant and nonmigrant labour activists may have different political cultures which can cause tension, as seen in LAWAS's relationship with Unite and Strangers into Citizens. 
Thus, when taking into account the enduring relevance of class, its intersectional collective and contentious deployment, its cultural, non-material and emotional dimensions, the dichotomous distinction of 'old' vs. 'new' social movements put forward by the NSM scholars appears irrelevant if not misleading. The ditching of this distinction appears all the more compelling when considering that the labour movement engages with the community through 'social-movement unionism' and that it has outlived many of the so called 'new' social movements which have often transformed themselves into co-opted and bureaucratized organisations (e.g. see Però 2007a; 2007b).

In sum, this article has drawn upon the new sociology of class (with its appreciation of culture as an intrinsic and crucial dimension of class) to develop a critique of the way the cultural turn in sociology and social movements studies has treated class and class politics (i.e. downplaying them as obsolete and antithetical to culture and cultural politics). It has also suggested that as migrants' experiences of being classed cannot be assimilated to those of the sedentaristic population (Erel 2010) neither can their political agency and practices of citizenship. The article has used intersectional and anti-essentialist approaches originally informed by feminist theory (Anthias and Yuval-Davies 1992; Hill Collins 1998; YuvalDavies 2011) to question simplistic and essentialist framings of migrants' politics as being determined by the encounter of their ethnicity with the host society's institutional opportunities of mobilization. Finally, it has shown that issues of culture, identity, subjectivity, emotions and biography, need neither to be seen as incompatible with nor applied 'against' class-based collective actions, nor do they need to be limited to the examination of individual experiences and conditions of being classed. For this reason, the simultaneous and interconnected presence of material and non-material dimensions in contemporary collective engagements based on class (in intersection with other axes) seem to require renewed sociological attention.

\section{Acknowledgements}

This paper has benefitted from very valuable comments of two anonymous reviewers as well as from the insightful suggestions of Marek Korczynzski, John Solomos and Elisabetta Zontini. Thank you. 


\section{Bibliography}

Anderson, B. (2010) Mobilising Migrants, Making Citizens: Migrant Domestic Workers as Political Agents. Ethnic and Racial Studies, 33(1):60-74.

Anthias, F. (2001) The Material and the Symbolic in Theorising Stratification. British Journal of Sociology 52(3):367-390.

Anthias, F. (2005) Social Stratification and Social Inequality. In: Devine, F., Savage M., Scott J. and Crompton R. (eds.) Rethinking Class. Houndmills: Palgrave, 24-45.

Anthias F. and Yuval-Davies N. (1992) Racialised Boundaries. London: Routledge.

Back, L. et al (2012) Cultural Sociology. Oxford: Wiley-Blackwell.

Bottero, W. (2004) Class Identities and the Identities of Class. Sociology 38(5):985-1003.

Bottero, W. (2009) Class in the $21^{\text {st }}$ Century. In: Sveinsson, K. (ed.) Who Cares about the White Working Class? London: Runnymede Trust, 7-14.

Chimienti, M. (2011) Mobilization of Irregular Migrants in Europe. Ethnic and Racial Studies 34(8):1338-1356.

Cleaver, H. (2002) Work is Still the Central Issue! In: Dinerstein A. and Neary M. (eds.) (2002). The Labour Debate. Aldershot: Ashgate, 135-148.

Coole, D. (1996) Is Class a Difference that Makes a Difference? Radical Philosophy 77:1725.

Crehan, K. (2002) Gramsci, Culture and Anthropology. London: Pluto

Crossely N. (2002) Making sense of Social Movements. Buckingham: Open University Press.

Della Porta, D. and Diani, D. (2006) Social Movements. $2^{\text {nd }}$ ed. Oxford: Blackwell.

Devine, F. and Savage, M. (2005) The Cultural Turn, Sociology and Class Analysis. In:

Devine, F., Savage M., Scott J. and Crompton R. (eds.) Rethinking Class. Houndmills:

Palgrave, 1-22.

Dinerstein A. and Neary M. (2002) From Here to Utopia: Finding Inspiration for the Labour Debate. In: Dinerstein A. and Neary M. (eds.) (2002). The Labour Debate. Aldershot: Ashgate, 1-26.

Dworkin, D. (2007) Class Struggles. London: Pearson Longman. 
Eder, K. (1985). The 'new social movements': moral crusades, political pressure groups, or social movements? Social Research 52:869-890.

Erel, U. (2010) Migrant Cultural Capital: Bordieu in Migration Studies. Sociology 44(4):642660 .

Espiritu, Y.L. (1992). Asian American panethnicity: Bridging institutions and identities. Philadelphia: Temple University Press.

Fraser, N. (2000) Rethinking Recognition. New Left Review 3:107-120.

Fraser, N. (2005) Mapping the Feminist Imagination. Constellations 12(3):292-307

Gillies, V. (2007) Marginalised Mothers. London: Routledge.

Gilroy, P. (2002) There Ain't No Black in the Union Jack. London: Routledge

Glick Schiller, N. (2008) Beyond Methodological Ethnicity. IMER-MIM Working Paper 2/08. Malmö: Malmö University.

Goldthorpe, J. (1996) Class Analysis and the Reorientation of Class Theory, British Journal of Sociology 26(3): 381-400.

Gibson-Graham, J.K., Resnik S. and Wolf R. (eds) (2000) Class and its Others. Minneapolis: University of Minnesota Press.

Gledhill, J. (2000) Power and its Disguises. London: Pluto.

Goodwin, J. and Jasper, J. (2009) Editors' Introduction. Goodwin, J. and Jasper, J. (eds.) The Social Movements Reader, $2^{\text {nd }}$ ed. Oxford: Wiley-Blackwell, pp. 1-8.

Goodwin, J. and Jasper, J. (eds.) (2009) The Social Movements Reader, $2^{\text {nd }}$ ed. Oxford: Wiley-Blackwell.

Gorz, A. (1982) Farewell to the Working Class. London: Pluto.

Gramsci, A. (1971) Selections from the Prison Notebooks. London: Lawrence and Wishart.

Grillo, R. (2005) Backlash Against Diversity?, COMPAS Working Paper 14. University of Oxford.

Hearn, J. and Bergos, M. (2011) Latin American Cleaners Fight for Survival. Race \& Class, 53(1):65-82.

Hill Collins, P. (1998) It's All In the Family: Intersections of Gender, Race, and Nation. Hypatia 13(3):62-82.

Holgate, J. (2005) Organizing Migrant Workers. Work, Employment and Society 19(3): 463480. 
Holloway, J. (2002) Class and Classification: Against, In and Beyond Labour. In: Dinerstein, A. and Neary, M. (eds.) The Labour Debate. Aldershot: Ashgate, 27-40.

Joyce, P. (1995) Introduction. In: Joyce P. Class. Oxford: OUP.

Kelly, P. and Lusis, T. (2006) Migration and the Transnational Habitus. Environment and Planning A 38:831-847

Korczynski, M. and Zhang, J. (2013) From Labourers of Love to Labourers with Rights. Unpublished Manuscript.

Kundnani, A. (2007) The End of Tolerance. London: Pluto.

Lawler, S. (2000) Mothering the Self. London: Routledge.

Laclau, E. (1984) The Making of Political Identities. London: Verso

Lentin, A. and Titley. G. (2011) The Crisis of Multiculturalism. London: Zed.

Lopez Rodriguez, M. (2010) Migration and a Quest for 'Normalcy', Social Identities 16(3):339-358.

McIlwaine, C., Cock, J. and Linneker, B. (2011) No Longer Invisible. London: Queen Mary University.

Marshall, G. (1997) Repositioning Class. London: Sage.

Martínez Lucio, M. and Perret, R. (2009) The Diversity and Politics of Trade Unions' Responses to Minority Ethnic and Migrant Workers. Economic and Industrial Democracy 30(3):324-347.

Marcus, G. E. (1995). Ethnography in/of the world system: the emergence of multi-sited ethnography. Annual Review of Anthropology, 95-117.

Mayo, M. (2005) Global Citizens. London: Zed.

McGhee, D. (2008) The End of Multiculturalism? Maidenhead: Open University Press.

McNevin, A. (2011) Contesting Citizenship. New: York: Columbia University Press.

Meiksins, Wood, E. (1998) The Retreat from Class. London: Verso.

Melucci, A. (1989) Nomads of the Present. London: Hutchinson Radius.

Milner, A. (1999) Class. London: Sage.

Moody, K. (1997) Workers in a Lean World. London: Verso.

Moschonas, G. (2002) In the Name of Social Democracy. London: Verso.

Munck, R. (2000) Globalisation and Labour. London: Zed. 
Nash, K. (2010) Contemporary Political Sociology. Oxford: Blackwell.

Offe, K. (1985) Disorganized Capitalism. Cambridge, MA: MIT Press.

Okely, J. (1994) Thinking through Fieldwork. In Bryman, A. and Burgess, G. (eds.)

Analysing Qualitative Data. London: Routledge, 18-34.

Okely, J. (2012) Anthropological Practice. Oxford: Berg.

Ortner, S. (2006) Anthropology and Social Theory. Durham: Duke University Press.

Però, D. (2007a) Inclusionary Rhetoric / Exclusionary Practices. Left-wing Politics and Migrants in Italy. New York: Berghahn.

Però, D. (2007b) Migrants and the Politics of Governance. Social Anthropology 15(3): 271286.

Però, D. (2008) Political Engagements of Latin Americans in the UK. Issues, Strategies and the Public Debate. Focaal 51: 73-90.

Però, D. (2011) Migrants' Practices of Citizenship and Policy Change. In Shore C., Wright S. and Però D. Policy Worlds. Anthropology and the Analysis of Contemporary Power. New York: Berghahn, 244-263.

Però, D. (2013) Migrants, Cohesion and the Cultural Politics of the State. Critical Perspectives on the Management of Diversity. Journal of Ethnic and Migration Studies 39(8): 1241-1259.

Però, D. and Solomos, J. (2010) Migrant Politics and Mobilization: Exclusion, Engagements, Incorporation. Ethnic and Racial Studies 33(1): 1-18.

Polletta, F. and Jasper, J. (2001) Collective Identity and Social Movements. Annual Review of Sociology 27: 283-305.

Pratt, J. (2003) Class, Nation and Identity. London: Pluto.

Reay, D. (2005) Rethinking Social Class.: Qualitative Perspectives on Gender and Social Class. Sociology, 32(2):259-75.

Reay, D. (2011) A New Social Class Paradigm. Bridging Individual and Collective, Cultural and Economic in Class Theory Sociology BSA $60^{\text {th }}$ Anniversary Special Collection: 1-4.

Rifkin, J. (1995) The End of Work. N.Y. Tarcher/Putnam.

Ryan, L. (2006) Rethinking Social Movement Theories in the Twenty-first Century. Sociology 40(1):169-176.

Savage, M. (2000) Class Analysis and Social Transformation. Buckingham: Open University Press. 
Sayer, A. (2005) The Moral Significance of Class. Cambridge: CUP

Scott, J. (1985) Weapons of the Weak. New Haven: Yale University Press.

Skeggs, B. (1997) Formations of Class and Gender. London: Sage

Skeggs, B. (2004) Class, Self, Culture. London: Routledge.

Spivak, G.C. (1996) Subaltern Studies Deconstructing Historiography 203-235. In Landry, D. and MacLean, G (eds.): The Spivak Reader. London: Routledge, 203-235.

Standing, G. (2009) Work after Globalization. Cheltenam: Edward Elgar.

Standing, G. (2011) The Precariat. London: Bloomsbury.

Touraine, A. (1971) The Post-Industrial Society. New York: Random House.

Touraine, A. (1981) The Voice and the Eye. Cambridge:CUP.

Vertovec, S. (2006) The Emergence of Super-Diversity in Britain, COMPAS Working Paper 25. Oxford: University of Oxford.

Williams, R. (1977) Marxism and Literature. Oxford: OUP.

Wills, J. (2008), Making Class Politics Possible: Organising Contract Cleaners in London. International Journal of Urban and Regional Research 32(2):305-23.

Wills, J., Datta, K., Evans, Y., Herbert, J., May, J., McIlwaine, C. (2010) Global Cities at Work. London: Pluto.

Yuval Davies, N. (2011) The Politics of Belonging. London: Sage

Davide Però is Lecturer in Sociology at the University of Nottingham where he teaches migration and politics and qualitative research. Previously he was Researcher at the Centre on Migration, Policy and Society of the University of Oxford. He is interested in class politics, culture, intersectionality and migrants' integration. Davide has conducted ethnographic research in Britain, Italy and Spain. His recent publications include an article on migrants, cohesion and the cultural politics of the British state in the Journal of Ethnic and Migration Studies 39(8) and a special issues of Ethnic and Racial Studies 33(1) on migrant mobilisations guest-edited with John Solomos.

\section{Corresponding Author:}

Dr Davide Però, School of Sociology and Social Policy, University of Nottingham, Law and Social Sciences Building, Park Campus, Nottingham NG7 2RD, UK.

Email: davide.pero@nottingham.ac.uk 


\begin{abstract}
${ }^{1}$ As pointed out by Bottero (2004), with the exception of a few authors working on a 'restricted' notion of class conceived in terms of occupation and social mobility (e.g. Goldthorpe 1996; Marshall 1997), this dimension of social inequality was relinquished to the margins of sociological enquiry.

${ }^{2}$ In sociological disciplines, class is taken to refer to a wide range of issues (see Back et al 2012; Pratt 2003; Sayer 2005). This article, while subscribing to the generic and rather 'neutral' definition of class as 'structured economic inequality' (Coole 1996: 17), also draws on a more specific one of class as 'a set of relationships involved in the production, appropriation and distribution of surplus' (Wills 2008: 309; see also Gibson-Graham et al. 2000). The latter is appealing because it reflects more its dynamic, relational and contentious aspects, as well as its ubiquitous, capillary and contingent character, recognising that class extends beyond the boundaries of the workplace and that - as Gilroy (2002) observed - can assume a range of different guises.
\end{abstract}

${ }^{3}$ All the informants' names appearing in this article are pseudonyms. 